\section{SANKSI ADMINISTRATIF ATAS PELANGGARAN KETENTUAN KESELAMATAN DAN KEAMANAN DALAM PESAWAT UDARA SELAMA PENERBANGAN ${ }^{1}$ \\ Oleh : Theresa Merry Monica Darenta ${ }^{2}$}

\begin{abstract}
ABSTRAK
Penelitian ini dilakukan dengan tujuan untuk mengetahui bagaimana pelanggaran administrasi atas ketentuan keselamatan dan keamanan dalam pesawat udara selama penerbangan dan bagaimana sanksi administratif atas pelanggaran ketentuan keselamatan dan keamanan dalam pesawat udara selama penerbangan. Dengan menggunakan metode penelitian yuridis normatif, disimpulkan: 1. Pelanggaran administrasi atas ketentuan keselamatan dan keamanan dalam pesawat udara selama penerbangan, seperti pesawat udara sipil Indonesia atau asing yang tiba di atau berangkat dari Indonesia tidak mendarat atau lepas landas dari bandar udara yang ditetapkan untuk itu, kecuali terjadi keadaan darurat dan pelanggaran atas larangan menerbangkan atau mengoperasikan pesawat udara yang dapat membahayakan keselamatan pesawat udara, penumpang dan barang, dan/atau penduduk atau mengganggu keamanan dan ketertiban umum atau merugikan harta benda milik orang lain. 2. Sanksi administratif atas pelanggaran ketentuan keselamatan dan keamanan dalam pesawat udara selama penerbangan sesuai dengan peraturan perundang-undangan yang berlaku melalui bentuk peringatan; pembekuan sertifikat; dan/atau pencabutan sertifikat.

Kata kunci: Sanksi Administratif, Pelanggaran, Keselamatan dan Keamanan, Dalam Pesawat Udara, Selama Penerbangan
\end{abstract}

\section{PENDAHULUAN}

\section{A. Latar Belakang}

Penerbangan sebagai satu kesatuan sistem yang terdiri atas pemanfaatan wilayah udara, pesawat udara, bandar udara, angkutan udara, keselamatan dan keamanan, lingkungan hidup, serta fasilitas penunjang dan fasilitas umum lainnya yang pokok-pokoknya dapat diuraikan

\footnotetext{
${ }^{1}$ Artikel Skripsi. Dosen Pembimbing: Hengky Adolf Korompis, SH., MH; Djoly A. Sualang, SH., MH

${ }^{2}$ Mahasiswa pada Fakultas Hukum Unsrat, NIM. 16071101543
}

sebagai berikut: huruf (a) Pemanfaatan wilayah udara merupakan implementasi dari kedaulatan Negara Republik Indonesia yang utuh dan eksklusif atas ruang udaranya, yang memuat tatanan ruang udara nasional, penyelenggaraan pelayanan, personel dan fasilitas navigasi penerbangan, serta pengaturan tentang tata cara navigasi, komunikasi penerbangan, pengamatan dan larangan mengganggu pelayanan navigasi penerbangan, termasuk pemberian sanksi. Tatanan ruang udara nasional ditetapkan untuk mewujudkan penyelenggaraan pelayanan navigasi penerbangan yang andal dalam rangka keselamatan penerbangan dengan mengacu pada peraturan nasional dan regulasi Organisasi Penerbangan Sipil Internasional (International Civil Aviation Organisation/ICAO) yang terkait dengan penetapan dan penggunaan ruang udara. Dalam penggunaan ruang udara tersebut, diberikan pelayanan oleh Pemerintah selaku penyelenggara pelayanan navigasi penerbangan, terdiri atas pelayanan lalu lintas penerbangan, komunikasi penerbangan, informasi aeronautika, informasi meteorologi penerbangan, serta informasi pencarian dan pertolongan. $^{3}$

Kecelakaan pesawat udara secara umum selalu dihubungkan dengan tiga faktor penyebab, yaitu faktor kesalahan manusia (human error), faktor pesawat terbang (machine), dan faktor lain seperti cuaca, dan lain-lain. Menurut statistik, faktor kesalahan manusia mempunyai adil paling besar, disusul faktor pesawat terbang dan yang terakhir faktor cuaca. Ketiga faktor penyebab tersebut biasanya tidak berdiri sendiri, melainkan bisa merupakan gabungan dari dua atau tiga faktor

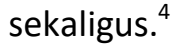

Kesalahan manusia yang dapat menyebabkan timbulnya kecelakaan telah diminimalisir dengan dilakukannya pemeriksaan rutin dan berkala bagi para personel penerbangan, khususnya bagi para personel yang berkaitan langsung dengan aktivitas rutin penerbangan. Pemeriksaan secara berkala tersebut merupakan suatu

\footnotetext{
${ }^{3}$ Penjelasan Atas Undang-Undang Nomor 1 Tahun 2009 Tentang Penerbangan.

${ }^{4}$ Anwar. Tinjauan Yuridis Dalam Tindak Pidana

Penerbangan Di Indonesia. Legal Pluralism: Volume 3 Nomor 1, Januari 2013. hlm. 40.
} 
kewajiban bagi setiap personel penerbangan yang telah memiliki sertifikat kecakapan ataupun lisensi sesuai dengan bidangnya masing-masing, hal tersebut lebih dipertegas dalam Pasal 223 ayat (1) Undang-Undang Nomor 1 Tahun 2009. Tujuan dari pemeriksaan secara berkala atas personel penerbangan tersebut adalah agar dapat diketahui secara pasti terkait hal-hal yang dapat mempengaruhi kinerja dari setiap personel sehingga dapat dihindari hal-hal yang dapat membahayakan keselamatan dan keamanan suatu misi penerbangan. ${ }^{5}$

Dilakukannya pemeriksaan secara berkala dan rutin terhadap personel penerbangan menjadi suatu tolak ukur ataupun standarisasi bahwa suatu penerbangan bukanlah bidang yang biasa-biasa saja, melainkan dibutuhkan suatu keseriusan dan ketelitian dalam segala aspek yang berkaitan, sehingga apabila dilakukan suatu pelanggaran atas ketentuan yang telah ditetapkan secara khusus tersebut, maka dapat disimpulkan bahwa pelanggaran tersebut dapat berakibat pada timbulnya kecelakaan yang fatal. ${ }^{6}$

Apabila terjadi pelanggaran administrasi atas ketentuan keselamatan dan keamanan dalam pesawat udara selama penerbangan, sebagaimana diatur dalam Undang-Undang Nomor 1 Tahun 2009 tentang Penerbangan, maka bagi pelakunya dapat dikenakan sanksi administratif.

\section{B. Rumusan Masalah}

1. Bagaimanakah pelanggaran administrasi atas ketentuan keselamatan dan keamanan dalam pesawat udara selama penerbangan?

2. Bagaimanakah sanksi administratif atas pelanggaran ketentuan keselamatan dan keamanan dalam pesawat udara selama penerbangan?

\section{Metode Penelitian}

Penelitian hukum yang dilakukan dengan cara meneliti bahan pustaka atau data sekunder belaka, dapat dinamakan penelitian hukum normatif atau penelitian hukum kepustakaan (di samping adanya penelitian hukum sosiologis atau empiris yang terutama

\footnotetext{
${ }^{5}$ Ibid. hlm. 41.

${ }^{6}$ Ibid. hlm. 41.
}

meneliti data primer). ${ }^{7}$ Penelitian hukum normatif digunakan dalam menyusun penulisan ini. Metode penelitian hukum normatif menggunakan bahan-bahan hukum yang dikumpulkan melalui studi kepustakaan.

\section{PEMBAHASAN}

A. Pelanggaran Administrasi Atas Ketentuan Keselamatan Dan Keamanan Dalam Pesawat Udara Selama Penerbangan

Keselamatan Penerbangan adalah suatu keadaan terpenuhinya persyaratan keselamatan dalam pemanfaatan wilayah udara, pesawat udara, bandar udara, angkutan udara, navigasi penerbangan, serta fasilitas penunjang dan fasilitas umum lainnya. ${ }^{8}$ Keamanan Penerbangan adalah suatu keadaan yang memberikan perlindungan kepada penerbangan dari tindakan melawan hukum melalui keterpaduan pemanfaatan sumber daya manusia, fasilitas, dan prosedur. ${ }^{9}$

Peraturan Menteri Perhubungan Republik Indonesia Nomor PM 78 Tahun 2017 Tentang Pengenaan Sanksi Administratif Terhadap Pelanggaran Peraturan Perundang-Undangan Di Bidang Penerbangan. Pasal 1 angka 2. Pelanggaran adalah penyimpangan terhadap ketentuan peraturan perundang-undangan di bidang penerbangan.

Peraturan Menteri Perhubungan Republik Indonesia Nomor PM 78 Tahun 2017 Tentang Pengenaan Sanksi Administratif Terhadap Pelanggaran Peraturan Perundang-Undangan Di Bidang Penerbangan. Pasal 11 ayat:

(1) Sanksi administratif sebagaimana dimaksud dalam Pasal 3 berupa :
a. peringatan;
b. pembekuan;
c. pencabutan; dan/atau
d. denda administratif.
(1) Pengenaan sanksi administratif sebagaimana dimaksud pada ayat (1), tercantum dalam Lampiran yang merupakan bagian tidak terpisahkan dari Peraturan Menteri ini.

\footnotetext{
${ }^{7}$ Soerjono Soekanto dan Sri Mamudji, Penelitian Hukum Normatif Suatu Tinjauan Singkat, PT Raja Grafindo Persada, Jakarta. 1995, hlm. 13-14.

${ }^{8}$ Pasal 1 angka 48 Undang-Undang Nomor 1 Tahun 2009 tentang Penerbangan.

${ }^{9}$ Pasal 1 angka 49 Undang-Undang Nomor 1 Tahun 2009 tentang Penerbangan.
} 
(2) Penerbitan surat sanksi administrasi berupa peringatan atau pembekuan, sebagaimana dimaksud pada ayat (1) huruf $a$ atau huruf $b$, yang bersamaan dengan pengenaan denda administratif sebagaimana dimaksud pada ayat (1) huruf $\mathrm{d}$, diterbitkan dengan tanggal dan bulan yang sama.

Pasal 12. Parameter pertimbangan, evaluasi dan analisa terkait penegakan hukum sebagaimana dimaksud dalam Pasal 9 ayat (2), dilakukan berdasarkan:

a. ancaman terhadap keamanan penerbangan;

b. resiko keselamatan penerbangan;

c. kepatuhan terhadap pemenuhan peraturan perundang- undangan;

d. pengulangan terjadinya pelanggaran yang sama; dan/atau

e. pelanggaran lebih dari satu. Pasal 13 ayat:

(1) Berdasarkan evaluasi dan analisa sebagaimana dimaksud dalam Pasal 12, hasil pemeriksaan pelanggaran peraturan perundang-undangan di bidang penerbangan yang terindikasi adanya tindak pidana bidang penerbangan, diserahkan kepada Penyidik Pegawai Negeri Sipil (PPNS).

(2) Pelanggar yang terbukti melakukan tindak pidana penerbangan sebagaimana dimaksud pada ayat (1), tidak menggugurkan kewajiban pemenuhan sanksi administratif.

Denda Administratif Terhadap

Keterlambatan Pembayaran. Pasal 14 ayat:

(1) Besaran denda administratif sebagaimana dimaksud dalam Pasal 11 huruf $d$, ditentukan dalam satuan denda administratif (penalty unit/PU), tercantum dalam Lampiran yang merupakan bagian tidak terpisahkan dari Peraturan Menteri ini.

(2) Satuan denda administratif (penalty unit/PU) sebagaimana dimaksud pada ayat (1) nilainya sebesar Rp100.000,-- (seratus ribu rupiah).

(3) Denda administratif sebagaimana dimaksud pada ayat (1), merupakan Penerimaan Negara Bukan Pajak di Lingkungan Direktorat Jenderal.

Pasal 15. Setiap keterlambatan pembayaran Penerimaan Negara Bukan Pajak sebagaimana dimaksud dalam Pasal 14 ayat (3), dikenakan denda sebesar $2 \%$ (dua persen) setelah 30 (tiga puluh) hari sejak dikeluarkannya nota tagihan dan berlaku kelipatannya setiap 30 (tiga puluh) hari pada hari berikutnya.

Pelanggaran administrasi atas ketentuan keselamatan dan keamanan dalam pesawat udara selama penerbangan yaitu:

1. Setiap pesawat udara sipil Indonesia atau asing yang tiba di atau berangkat dari Indonesia hanya dapat mendarat atau lepas landas dari bandar udara yang ditetapkan untuk itu. Ketentuan itu tidak berlaku dalam keadaan darurat. Pelanggaran atas ketentuan ini dapat dikenakan sanksi administrati.

2. Setiap orang dilarang menerbangkan atau mengoperasikan pesawat udara yang dapat membahayakan keselamatan pesawat udara, penumpang dan barang, dan/atau penduduk atau mengganggu keamanan dan ketertiban umum atau merugikan harta benda milik orang lain.

3. Setiap orang di dalam pesawat udara selama penerbangan dilarang melakukan perbuatan yang dapat membahayakan keamanan dan keselamatan penerbangan; pelanggaran tata tertib dalam penerbangan; pengambilan atau pengrusakan peralatan pesawat udara yang dapat membahayakan keselamatan; perbuatan asusila; perbuatan yang mengganggu ketenteraman; atau pengoperasian peralatan elektronika yang mengganggu navigasi penerbangan.

4. Dalam penerbangan dilarang menempatkan penumpang yang tidak mampu melakukan tindakan darurat pada pintu dan jendela darurat pesawat udara.

\section{B. Sanksi Administratif Atas Pelanggaran Ketentuan Keselamatan Dan Keamanan Dalam Pesawat Udara Selama Penerbangan}

Sanksi administrasi merupakan perbuatan pemerintah guna mengakhiri suatu keadaan yang dilarang oleh kaidah hukum administrasi atau melakukan apa yang seharusnya ditinggalkan oleh para warga masyarakat 
karena bertentangan dengan undang-undang atau aturan hukum lainnya. ${ }^{10}$

Penempatan sanksi dalam suatu aturan hukum, merupakan bagian penutup yang sangat penting dalam setiap peraturan perundang-undangan termasuk dalam aturan hukum administrasi. Pada umumnya tidak ada gunanya memasukkan aturan-aturan hukum tentang kewajiban-kewajiban atau laranganlarangan bagi para warga dalam aturan hukum bidang administrasi negara, manakala aturanaturan mengenai tingkah laku tidak dapat dipaksakan secara tegas oleh aparat pemerintah atau lembaga/instansi maupun pejabat yang berwenang untuk itu. ${ }^{11}$

Pengangkutan udara, sebagai salah satu bentuk penerbangan sipil, mempunyai misi untuk mengangkut penumpang, barang-barang pos dan kargo dengan selamat dan tepat waktu sampai tujuan. Untuk itu keselamatan, efisiensi, dan keteraturan dalam pengangkutan udara merupakan hal yang sangat penting. Setiap gangguan terhadap pengangkutan udara akan merugikan bukan saja para penumpang dan pengirim kargo, melainkan juga akan membahayakan pesawat udara dan pengangkutan udara itu sendiri. ${ }^{12}$

Peraturan Menteri Perhubungan Republik Indonesia Nomor Pm 78 Tahun 2017 Tentang Pengenaan Sanksi Administratif Terhadap Pelanggaran Peraturan Perundang-Undangan Di Bidang Penerbangan. Pasal 2. Pengenaan sanksi administratif bertujuan untuk:

a. meningkatkan kesadaran dan ketaatan operator dan personel penerbangan terhadap peraturan perundangundangan; dan

b. menumbuhkan budaya keselamatan penerbangan.

Undang-Undang Nomor 1 Tahun 2009 tentang Penerbangan. Keselamatan dan Keamanan dalam Pesawat Udara Selama Penerbangan. Pasal 52 ayat:

\footnotetext{
${ }^{10}$ Philipus. M. Hadjon. Pengantar Hukum Administrasi Indonesia. Gadjah Mada University Press, Yogyakarta 1994. hlm. 246.

${ }^{11} \mathrm{Ibid}, \mathrm{hlm} .245$.

${ }^{12}$ Tien Saefullah, "Status dan Tanggung Jawab Awak Pesawat Udara Dalam Hukum Nasional Indonesia" dalam Oentoeng Wahjoe dan M Husni Syam (Editor), Kapita Selekta Hukum Internasional, Pusat Penerbitan Universitas - LPPM UNISBA, 2010, HIm. 283.
}

(1) Setiap pesawat udara sipil Indonesia atau asing yang tiba di atau berangkat dari Indonesia hanya dapat mendarat atau lepas landas dari bandar udara yang ditetapkan untuk itu.

(2) Ketentuan sebagaimana dimaksud pada ayat (1) tidak berlaku dalam keadaan darurat.

(3) Setiap orang yang melanggar ketentuan sebagaimana dimaksud pada ayat (1) dikenakan sanksi administratif berupa:

a. peringatan;

b. pembekuan sertifikat; dan/atau

c. pencabutan sertifikat.

Pasal 53 ayat:

(4) Setiap orang dilarang menerbangkan atau mengoperasikan pesawat udara yang dapat membahayakan keselamatan pesawat udara, penumpang dan barang, dan/atau penduduk atau mengganggu keamanan dan ketertiban umum atau merugikan harta benda milik orang lain.

(5) Setiap orang yang melanggar ketentuan sebagaimana dimaksud pada ayat (1) dikenakan sanksi administratif berupa:

a. pembekuan sertifikat; dan/atau

b. pencabutan sertifikat.

Pasal 54. Setiap orang di dalam pesawat udara selama penerbangan dilarang melakukan:

a. perbuatan yang dapat membahayakan keamanan dan keselamatan penerbangan;

b. pelanggaran tata tertib dalam penerbangan;

c. pengambilan atau pengrusakan peralatan pesawat udara yang dapat membahayakan keselamatan;

d. perbuatan asusila;

e. perbuatan yang mengganggu ketenteraman; atau

f. pengoperasian peralatan elektronika yang mengganggu navigasi penerbangan.

Pasal 55. Selama terbang, kapten penerbang pesawat udara yang bersangkutan mempunyai wewenang mengambil tindakan untuk menjamin keselamatan, ketertiban, dan keamanan penerbangan.

Pasal 56 ayat:

(1) Dalam penerbangan dilarang menempatkan penumpang yang tidak mampu melakukan tindakan darurat pada pintu dan jendela darurat pesawat udara. 
(2) Setiap orang yang melanggar ketentuan sebagaimana dimaksud pada ayat (1) dikenakan sanksi administratif berupa:

a. peringatan;

b. pembekuan sertifikat; dan/atau

c. pencabutan sertifikat.

Pasal 57. Ketentuan lebih lanjut mengenai keselamatan dan keamanan dalam pesawat udara, kewenangan kapten penerbang selama penerbangan, dan pemberian sanksi administratif diatur dengan Peraturan Menteri.

Perbedaan antara sanksi administrasi dan sanksi pidana dapat dilihat dari tujuan pengenaan sanksi itu sendiri. Sanksi administrasi ditujukan kepada perbuatan pelanggarannya sedangkan sanksi pidana ditujukan kepada si pelanggar dengan memberi hukuman berupa nestapa. Sanksi administrasi dimaksudkan agar perbuatan pelanggaran itu dihentikan. Sifat sanksi adalah "reparatoir" artinya memulihkan pada keadaan semula. Di samping itu perbedaan antara sanksi pidana dan sanksi administrasi ialah tindakan penegakan hukumnya. Sanksi administrasi diterapkan oleh Pejabat Tata Usaha Negara tanpa harus melalui prosedur peradilan sedangkan sanksi pidana hanya dapat dijatuhkan oleh hakim pidana melalui proses peradilan. ${ }^{13}$

Penerapan sanksi pidana merupakan upaya terakhir (ultimum remedium) ketika instrumen hukum perdata atau hukum administrasi sudah tidak dapat dilaksanakan dengan baik. ${ }^{14}$

Menurut Philipus. M. Hadjon, wewenang menerapkan sanksi administrasi sebagai suatu konsep hukum publik terdiri atas sekurangkurangnya tiga komponen, yaitu:

a. komponen pengaruh; bahwa penggunaan wewenang dimaksudkan untuk mengendalikan perilaku subyek hukum,

b. komponen dasar hukum; bahwa wewenang itu selalu harus dapat ditunjuk dasar hukumnya, dan

c. komponen konformitas hukum; mengandung makna adanya standar

\footnotetext{
${ }^{13}$ Philipus. M. Hadjon, dkk. Pengantar Hukum Administrasi Indonesia (Introduction To The Indonesian Administrative Law) Gadjah Mada University Press. Yogyakarta. 2008. hlm. 247.

${ }^{14}$ Andi Hamzah. Asas-asas Hukum Pidana Indonesia.

Rineka Cipta. Jakarta, 2008. hlm. 8.
}

wewenang, yaitu standar umum (semua jenis wewenang) dan standar khusus (untuk jenis wewenang tertentu). ${ }^{15}$

Pelayanan publik diartikan dengan pemberian layanan (melayani) keperluan orang atau masyarakat yang mempunyai kepentingan pada organisasi itu sesuai dengan aturan pokok dan tata cara yang telah ditetapkan. ${ }^{16}$

Penarikan kembali keputusan sebagai sanksi ini berkaitan erat dengan sifat keputusan itu sendiri. Bila keputusan bersifat terikat, maka keputusan tersebut harus ditarik sendiri oleh organ atau instansi yang mengeluarkan keputusan. Penarikan ini hanya mungkin dilakukan apabila peraturan perundangundangan yang menjadi dasar dikeluarkannya keputusan telah mengaturnya sebelum keputusan itu dikeluarkan. Sedangkan keputusan yang bersifat bebas, maka penarikannya kadang-kadang ditentukan dalam peraturan perundang-undangan, kadangkadang tidak. ${ }^{17}$

Hal-hal yang dapat menjadikan sebab suatu keputusan tata usaha negara yang berupa perizinan dicabut sebagai bentuk sanksi adalah

1. Pihak yang berkepentingan (penerima izin) tidak mematuhi pembatasan-pembatasan, syarat-syarat atau ketentuan peraturan perundang-undangan yang dikaitkan pada izin tersebut;

2. Pihak yang berkepentingan (penerima izin) pada waktu mengajukan permohonan untuk mendapatkan izin telah memberikan data yang tidak benar atau tidak lengkap. Hal ini bermakna bahwa apabila data yang diberikan saat mengajukan permohonan izin benar, lengkap, dan tidak dipalsukan maka pemberian izin mungkin tidak akan diberikan (permohonan izin ditolak). ${ }^{18}$

Peraturan Menteri Perhubungan Republik Indonesia Nomor Pm 78 Tahun 2017 Tentang Pengenaan Sanksi Administratif Terhadap Pelanggaran Peraturan Perundang-Undangan Di Bidang Penerbangan. Pasal 17 ayat:

\footnotetext{
${ }^{15}$ Philipus. M. Hadjon, Op.Cit. hlm. 1.

${ }^{16}$ Lijan Poltak Sinambela. Reformasi Pelayanan Publik-

Teori, Kebijakan, Dan Implementasi. Bumi Aksara. Jakarta.

2006. hlm. 5.

${ }_{17}$ Ibid. hlm. 312

${ }^{18} \mathrm{Ibid}$.
} 
(1) Terhadap pengenaan Sanksi Administratif Pembekuan yang telah ditetapkan tercantum dalam Peraturan Menteri ini dan Pelanggar tidak dapat memenuhi kewajibannya maka Sanksi Administratif Pencabutan dapat diberlakukan dengan parameter pertimbangan, evaluasi dan analisa sebagaimana tercantum dalam Pasal 12.

(2) Terhadap pengenaan Sanksi Administratif berupa Denda Administratif sebagaimana dimaksud dalam Pasal 16 dan Pelanggar belum memenuhi kewajiban membayar denda administratif maka Sanksi Administratif Pencabutan dapat diberlakukan dengan parameter pertimbangan, evaluasi dan analisa sebagaimana tercantum dalam Pasal 12 huruf $c$, huruf $d$ dan/atau huruf e.

Peraturan Menteri Perhubungan Republik Indonesia Nomor PM 78 Tahun 2017 Tentang Pengenaan Sanksi Administratif Terhadap Pelanggaran Peraturan Perundang-Undangan Di Bidang Penerbangan.

Pasal 20 ayat:

(1) Pengenaan sanksi administratif yang sudah ditetapkan akan dipublikasikan melalui website Direktorat Jenderal.

(2) Informasi pengenaan sanksi administratif yang dipublikasikan sebagaimana dimaksud pada ayat (1), paling sedikit memuat data

a. pelanggaran;

b. jumlah pelanggaran; dan

c. identitas pelanggar.

Peraturan Menteri Perhubungan Republik Indonesia Nomor Pm 78 Tahun 2017 Tentang Pengenaan Sanksi Administratif Terhadap Pelanggaran Peraturan Perundang-Undangan Di Bidang Penerbangan. Pasal 18 ayat:

(1) Pelanggar yang dikenakan sanksi administratif dapat mengajukan usulan keberatan kepada Direktur Jenderal, paling lama dalam waktu 14 (empat belas) hari kerja sejak tanggal diterimanya penetapan sanksi administratif.

(2) Persetujuan atau penolakan terhadap usulan sebagaimana dimaksud pada ayat (1), ditetapkan oleh Direktur Jenderal paling lama 14 (empat belas) hari kerja, sejak tanggal diterimanya usulan keberatan.
(3) Persetujuan atau penolakan terhadap usulan sebagaimana dimaksud pada ayat (1), merupakan keputusan terakhir dan mengikat (final dan binding).

Pasal 19 ayat:

(1) Pelanggar setelah melaksanakan kewajiban atau upaya perbaikan sesuai dengan yang tercantum dalam sanksi peringatan, pembekuan atau denda administratif, harus melaporkan kepada Direktur atau Kepala Kantor dan Sekretaris Direktorat Jenderal untuk dilakukan evaluasi.

(2) Hasil evaluasi sebagaimana dimaksud pada ayat (1) akan dijadikan dasar tindak lanjut pengenaan sanksi.

Peraturan Menteri Perhubungan Republik Indonesia Nomor Pm 78 Tahun 2017 Tentang Pengenaan Sanksi Administratif Terhadap Pelanggaran Peraturan Perundang-Undangan Di Bidang Penerbangan, mengatur tentang Pengawasan Pasal 21. Direktur Jenderal melakukan pengawasan terhadap pelaksanaan Peraturan Menteri ini dan melaporkan hasil pengawasan kepada Menteri.

Pemberlakuan sanksi administratif atas pelanggaran ketentuan keselamatan dan keamanan dalam pesawat udara selama penerbangan sesuai dengan peraturan perundang-undangan dalam bentuk peringatan; pembekuan sertifikat; dan/atau pencabutan sertifikat.

Berkat rahmat Tuhan Yang Maha Esa Negara Kesatuan Republik Indonesia telah dianugerahi sebagai negara kepulauan yang terdiri dari beribu pulau, terletak memanjang di garis khatulistiwa, di antara dua benua dan dua samudera, serta ruang udara yang luas. Oleh karena itu, Indonesia mempunyai posisi dan peranan yang sangat penting dan strategis dalam hubungan internasional. Untuk mencapai tujuan pembangunan nasional sebagai pengamalan Pancasila dan UndangUndang Dasar Negara Republik Indonesia tahun 1945, mewujudkan Wawasan Nusantara serta memantapkan ketahanan nasional, diperlukan sistem transportasi nasional yang memiliki posisi penting dan strategis dalam pembangunan nasional yang berwawasan lingkungan. Transportasi juga merupakan sarana dalam memperlancar roda perekonomian, membuka akses ke daerah 
pedalaman atau terpencil, memperkukuh persatuan dan kesatuan bangsa, menegakkan kedaulatan negara, serta mempengaruhi semua aspek kehidupan masyarakat.

Pentingnya transportasi tercermin pada semakin meningkatnya kebutuhan jasa angkutan bagi mobilitas orang serta barang di dalam negeri, dari dan ke luar negeri, serta berperan sebagai pendorong, dan penggerak bagi pertumbuhan daerah dan pengembangan wilayah. Menyadari peran transportasi tersebut, penyelenggaraan penerbangan harus ditata dalam satu kesatuan sistem transportasi nasional secara terpadu dan mampu mewujudkan penyediaan jasa transportasi yang seimbang dengan tingkat kebutuhan, selamat, aman, efektif, dan efisien. Penerbangan yang mempunyai karakteristik dan keunggulan tersendiri, perlu dikembangkan agar mampu meningkatkan pelayanan yang lebih luas, baik domestik maupun internasional. Pengembangan penerbangan ditata dalam satu kesatuan sistem dengan mengintegrasikan dan mendinamisasikan prasarana dan sarana penerbangan, metoda, prosedur, dan peraturan sehingga berdaya guna serta berhasil guna.

\section{PENUTUP}

\section{A. Kesimpulan}

1. Pelanggaran administrasi atas ketentuan keselamatan dan keamanan dalam pesawat udara selama penerbangan, seperti pesawat udara sipil Indonesia atau asing yang tiba di atau berangkat dari Indonesia tidak mendarat atau lepas landas dari bandar udara yang ditetapkan untuk itu, kecuali terjadi keadaan darurat dan pelanggaran atas larangan menerbangkan atau mengoperasikan pesawat udara yang dapat membahayakan keselamatan pesawat udara, penumpang dan barang, dan/atau penduduk atau mengganggu keamanan dan ketertiban umum atau merugikan harta benda milik orang lain.

2. Sanksi administratif atas pelanggaran ketentuan keselamatan dan keamanan dalam pesawat udara selama penerbangan sesuai dengan peraturan perundang-undangan yang berlaku melalui bentuk peringatan; pembekuan sertifikat; dan/atau pencabutan sertifikat.

\section{B. Saran}

1. Agar supaya tidak dikenakan sanksi administratif, maka selama penerbangan seharusnya tidak melakukan perbuatan yang dapat membahayakan keamanan dan keselamatan penerbangan; pelanggaran tata tertib dalam penerbangan; pengambilan atau pengrusakan peralatan pesawat udara yang dapat membahayakan keselamatan; perbuatan asusila; perbuatan yang mengganggu ketenteraman; atau pengoperasian peralatan elektronika yang mengganggu navigasi penerbangan dan menempatkan penumpang yang tidak mampu melakukan tindakan darurat pada pintu dan jendela darurat pesawat udara.

2. Sanksi administratif atas pelanggaran ketentuan keselamatan dan keamanan dalam pesawat udara selama penerbangan perlu diterapkan sesuai dengan pelanggaran administrasi yang telah terbukti dilakukan dan pemberlakukan sanksi harus sesuai dengan tahapan seperti peringatan; pembekuan sertifikat; dan/atau pencabutan sertifikat.

\section{DAFTAR PUSTAKA}

Anwar. Tinjauan Yuridis Dalam Tindak Pidana Penerbangan Di Indonesia. Legal Pluralism: Volume 3 Nomor 1, Januari 2013.

Dimyati Khudzaifah dan Kelik Wardiono, "Metode Penelitian Hukum", Universitas Muhammadiyah Surakarta. 2004.

Djamali Abdoel. Pengantar Hukum Indonesia. Rajawali Pers. PT. Raja Grafindo Persada. Jakarta. 2009.

Hadjon $M$ Philipus. Pengantar Hukum Administrasi Indonesia. Gadjah Mada University Press, Yogyakarta 1994.

Hadjon M. Philipus., dkk. Pengantar Hukum Administrasi Indonesia (Introduction To The Indonesian Administrative Law) Gadjah Mada University Press. Yogyakarta. 2008. 
Hamzah Andi, Terminologi Hukum Pidana, (Editor) Tarmizi, Ed. 1. Cet. 1. Sinar Grafika, Jakarta, 2008.

Hamzah Andi. Asas-asas Hukum Pidana Indonesia. Rineka Cipta. Jakarta, 2008.

Hariri Muhwan Wawan. Pengantar IImu Hukum, Cet. 1. CV. Pustaka Setia Bandung. 2012.

HR Ridwan, Hukum Adminstrasi Negara, Edisi I. Cet. 4. PT. RadjaGrafindo, Jakarta, 2006.

Husni Lalu, Pengantar Hukum Ketenagakerjaan Indonesia, Edisi Revisi, PT. RajaGrafindo, Jakarta, 2008.

I. H. Ph. Diederiks-Verschoor, "Hukum Udara dan Hukum Ruang Angkasa", Sinar Grafika, Jakarta. 1991.

Likadja Frans, Masalah Lintas di Ruang Udara, Binacipta, 1987.

Machmud Syahrul. Penegakan Hukum Lingkungan Indonesia. (Penegakan Hukum Administrasi. Hukum Perdata. Dan Hukum Pidana Menurut UndangUndang No. 32 Tahun 2009) Graha Ilmu. Yogyakarta.Graha IImu, Bandung. 2012.

Mahmud Marzuki Peter, Penelitian Hukum, Edisi Pertama Cetakan ke-2, Kencana Prenada Media Group, Jakarta, 2006.

Martono H.K. dan Amad Sudiro, Hukum Udara Nasional dan Internasional Publik (Public International and National Air Law). Rajawali Pers. Jakarta. 2012.

Martono H.K. dan Amad Sudiro, Hukum Udara Nasional dan Internasional Publik (Public International And National Air Law). Ed. I. Cetakan ke-I. PT. RajaGrafindo, Jakarta, 2012.

Martono H.K., Eka Budi Tjahjono, Yogi Ashari, Wynd Rizaldy dan Muhammad Rifni, Transportasi Bahan dan/atau Barang Berbahaya Dengan Pesawat Udara Berdasarkan UURI No. 1 Tahun 2009. Edisi I. Cetakan Ke- I. PT. RajaGrafindo Persada, Jakarta. 2011.

Masriani Tiena Yulies. Pengantar Hukum Indonesia, Cetakan Kelima, Sinar Grafika, Jakarta. 2009.

Muhammad Nuh. Etika Profesi Hukum. CV. Pustaka Setia. Bandung. 2011.
Ningrum Lestari, Usaha Perjalanan Wisata Dalam Perspektif Hukum Bisnis, Citra Aditya Bakti, Bandung. 2004.

Purbopranoto Kuntjoro, Perkembangan Hukum Administrasi Indonesia, Binacipta, Jakarta, 1981.

Putra Bagus Wyasa Ida, Hukum Bisnis Pariwisata, Cetakan Pertama. PT. Refika Aditama, Bandung, 2003.

Rahardjo Satjipto, IImu Hukum, Cetakan ke- IV, PT. Citra Aditya Bakti, Bandung, 2006. . Hukum dan Perubahan Sosial Suatu Tinjauan Teoretis Serta PengalamanPengalaman di Indonesia. Cetakan Ketiga Genta Publishing. Yogyakarta. 2009.

Rahardjo Satjipto, IImu Hukum, Cetakan ke- IV, PT. Citra Aditya Bakti, Bandung, 2006.

Sadjijono. Polri Dalam Perkembangan Hukum Di Indonesia, (Editor) M. Khoidin, LaksBang PRESSindo, Yogyakarta. 2008.

Saefullah Tien, "Status dan Tanggung Jawab Awak Pesawat Udara Dalam Hukum Nasional Indonesia" dalam Oentoeng Wahjoe dan M Husni Syam (Editor), Kapita Selekta Hukum Internasional, Pusat Penerbitan Universitas - LPPM UNISBA, 2010.

Silondae Akbar Arus dan Wirawan B. Ilyas. Pokok-Pokok Hukum Bisnis. Salemba Empat. Jakarta. 2011.

Sinambela Poltak Lijan. Reformasi Pelayanan Publik-Teori, Kebijakan, Dan Implementasi. Bumi Aksara. Jakarta. 2006.

Soekanto Soerjono dan Sri Mamudji, Penelitian Hukum Normatif Suatu Tinjauan Singkat, PT Raja Grafindo Persada, Jakarta. 1995.

Sudarsono, Pengantar Ilmu Hukum, Cetakan Kelima, PT. Rineka Cipta, Jakarta, 2007.

Suherman, E. Hukum Udara Indonesia dan Internasional.Alumni. Bandung, 1983.

Supriadi dan Alimudin, Hukum Perikanan Indonesia, Cetakan Pertama, Sinar Grafika, Jakarta, 2011.

Thontowi Jawahir. Pengantar Ilmu Hukum. Pustaka Fahima. Yogjakarta. 2007. 
Titik Triwulan Tutik, Pengantar Hukum Perdata di Indonesia, Cetakan Pertama, Jakarta, 2006.

Usman, Aspek-Aspek Hukum Perbankan di Indonesia. Penerbit Gramedia Pustaka Utama. Jakarta. 2001.

Wawan Muhwan Hariri. Pengantar IImu Hukum, Cet. 1. CV. Pustaka Setia Bandung. 2012. 